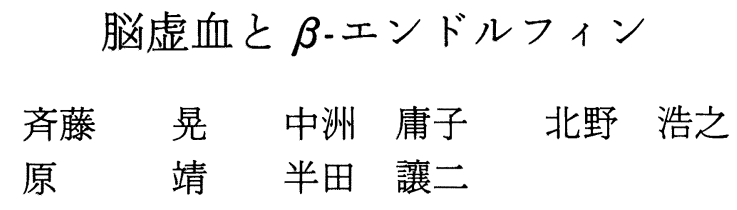

要旨：くも膜下出血以外の疾患で開頭術を行なった12例，開頭術を行なわなかった 9 例を対 照として, 脳動脈瘤急性期手術例, 脳梗塞急性期例の血浆中, 髄液中 $\beta$-エンドルフィンの変動 を検討した。

開頭術自身は術後急性期の血浆中，髄液中 $\beta$-エンドルフィン値に有意の変化を来さない。脳 動脈瘤急性期手術例でも, 挛縮による虚血症状の有無に拘らず $\beta$-エンドルフィン值の有意の変 化はみられず，急性期脳梗塞例も同様であった。

Key words : $\beta$-endorphin, opioid receptor, cerebral ischemia, cerebral aneurysm, vasospasm

(脳卒中 $8: 208-212,1986$ )

\section{I.はじめに}

Opioid receptorの競合的拮抗物質であるnaloxone が脳虚血による神経脱落症状を改善させたとする報 告2)以来, 脳・春髄虚血に対する naloxone の有用性を 支持する報告12)667)12) 14)22)28)33) とこれを否定する報 告1013115)がみられ，現在な掞この点に関しては一定の 結論を得るには到っていない。 また虚血神経組織に対 する naloxone の作用メカニズムも類推の域を出てい な(.719)33).さらに脳虚血時の $\beta$-エンドルフィンの変 動について調べた報告もごく少数みられるにすぎな ( ${ }^{6}$. 我々は脳虚血時の $\beta$-エンドルフィンの変化, 特に くも膜下出血後の血管挛縮による脳虚血症状と $\beta$-エ ンドルフィンとの関係について調べた。

\section{II. 対象と方法}

対象とした症例は全部で64例で，これらを

第 1 群：〈も膜下出血以外の疾患で脳虚血症状のな かった症例一 21 例

第 2 群：〈も膜下出血で急性期手術を施行し, 血管 挛縮による神経脱落症状のなかった症例一23例

第 3 群 : くも膜下出血で急性期手術を施行し, 血管 挛縮による神経脱落症状を呈した症例一13例

第 4 群：脳梗塞急性期症例 -7 例

滋賀医科大学脳神経外科
の 4 群に分けた。

第 1 群には開頭術施行例12例と開頭術非施行例 9 例 が含まれている．第 2,3 群については発症当日又は, 翌日に手術がなされて打り，発症後日数と術後日数が ほぼ一致する。また第 3 群における脳虚血症状はいず れ子発症後 1 週間前後から出現し, 今回の調査期間中 であった。

第 1 群のうちの開頭例, および第 2,3 群の全例につ いては手術前日より隔日に術後11日目まで血浆中, 髄 液中の $\beta$-エンドルフィンを測定し，その変動をみた。 な敃発症当日に手術を施行された症例については, 術 前の $\beta$-エンドルフィンの値を手術前日の值とした。第 1 群の非開頭例については 1 回だけ検体を採取し，そ の結果を開頭例の手術前日の值に加えた。第 4 群につ いては発症後急性期に検体を 1 回採取した。

検体採取は午前中に 1 回, 血液は时静脈より, 髄液 は腰椎穿刺により行ない, $\beta$-エンドルフィンの測定に は RIA 法を用いた。 そして第 1 群を対照群として, 他 の 3 群と第 1 群との有意差を $\mathrm{t}$ 検定を用いて調べた。

\section{III. 結 果}

本測定法での血中 $\beta$-エンドルフィンの正常值は $14 \sim 70 \mathrm{pg} / \mathrm{m} l$, 髄液に拀いてはそれ以下である.

第 1 群（対照群）では術前値は正常範囲内にあり, また手術例では術前・術後を通じて血浆中・髄液中い ずれに颃いても $\beta$.エンドルフィンの值には大きな変 
Group 1

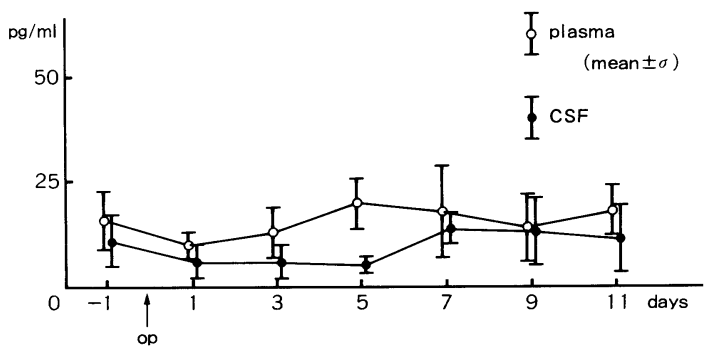

図 1 第 1 群 (対照群) の血浆中 (plasma), および髄 液中 $(\mathrm{CSF})$ の $\beta$-エンドルフィンの変動 (平均士 $\sigma$ ). day-1の值は, 手術例12例での手術前日の測定值, 非手術例 9 例の 1 回測定値を示す. day-1以降は手 術例のみの測定值.

Group 2.

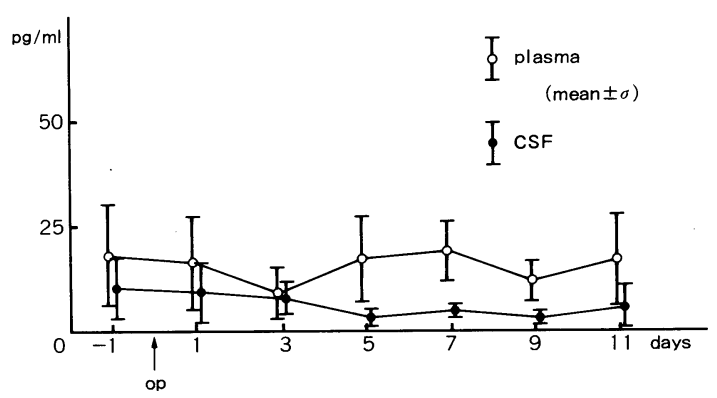

図 2 第 2 群 (動脈瘤急性期手術, 挛縮による虚血症 状のない群）の血浆中および髄液中の $\beta$-エンドル フィンの変動 (平均 $\pm \sigma$ ).

動は認められなかった（図 1 )。

第 2 群 (symptomatic vasospasm を示さなかった破 裂動脈瘤急性期手術群）に打いても $\beta$-エンドルフィン の值は手術前後を通じて大きな変動を示さず，その経 時的変化は第 1 群のそれに比し有意な差を示さなかっ た（図 2 ).

第 3 群 (symptomatic vasospasm を示した急性期手 術群)に扔いては，血浆中 $\beta$-ェンドルフィンについて はその值に他の群と比べて個人差おょび経過中の変動 が大きい傾向がみられたが，推計学的処理を行ならと 第 1 群との間に有意差を認めるには到らなかった（図 $3 \mathrm{a})$. 検体数は少ないが髄液中 $\beta$-エンドルフィンの 動向についても第 1 群との間に推計学的に有意差はみ られなかった (図 $3 \mathrm{~b})$. また, 第 3 群内で虚血症状の つよさと血浆中 $\beta$-エンドルフィンの間にも有意な関 係はみられなかった。

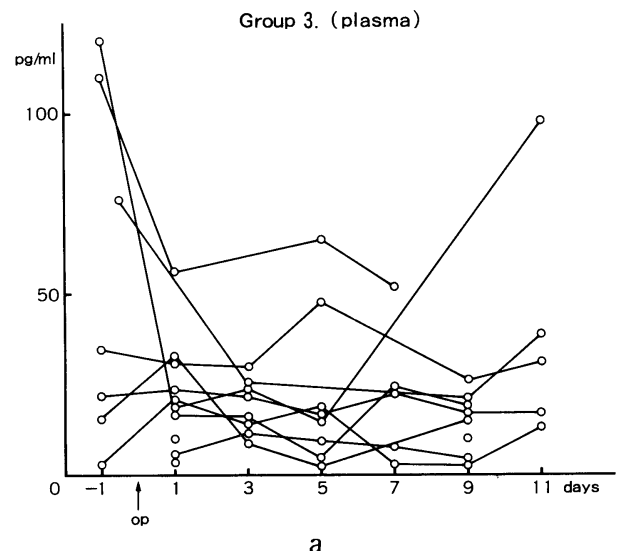

Group 3. (CSF)

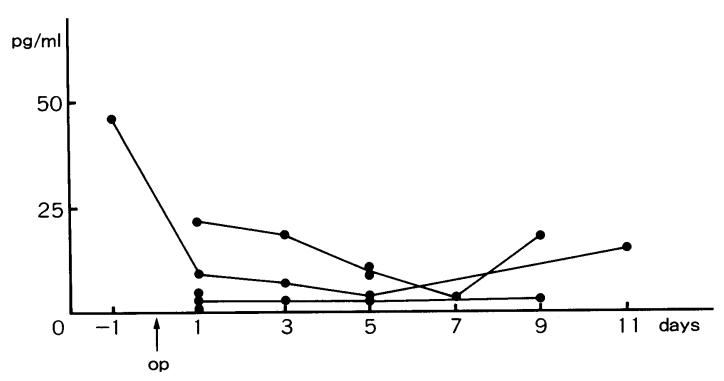

b

図 3 第 3 群（動脈瘤急性期手術, 挛縮発生群）の血 浆中（a）扣よび髄液中（b）の $\beta$-エンドルフィン の変動.

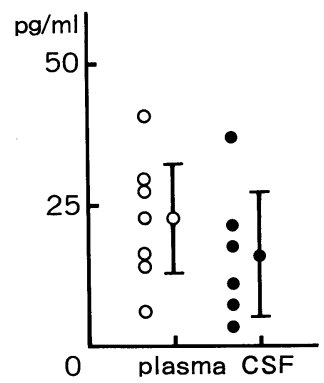

図 4 第 4 群 (脳梗塞急性期例) の血浆中, 髄液中 $\beta$ エンドルフィン值.

第 4 群 (脳梗塞急性期群) の $\beta$-エンドルフィンの値 は血浆中・髄液中のいずれかに拈いても第 1 群との間 に有意差を示さなかった（図 4 ）.

\section{IV. 考 察}

脳虚血症状と $\beta$-エンドルフィンとの関係について, 
くも膜下出血後の血管挛縮を呈した症例及び脳梗塞急 性期の症例を対象として調査を行なった。脳動脈瘤患 者は手術を受けているので, 手術操作自体の影響をみ るため, まずくも膜下出血以外の症例 21 例（第 1 群） のらち開頭術を行なった12例につき調べたが，その成 績から, 少なくとも開頭術といら手術侵襲のみでは $\beta$ エンドルフィンの值は影響を受けないと思われた。こ のことは矢尾らの報告 ${ }^{22)}$ と一致するものであった.

さらにこの第 1 群と比較した場合, くも膜下出血急 性期手術例計 36 例 (第 $2+3$ 群) でも, symptomatic vasospasm の有無にかかわらず, 血浆中 $\beta$-エンドル フィン值に推計学的に有意な一定の変化はみられな かった。 また symptomatic vasospasm を示した例で, ある時点での検体に正常範囲をこえた $\beta$-エンドル フィン值の上昇のみられた例があっても, 症状のつよ さや血管撮影所見の推移と $\beta$-エンドルフィン值の動 向の間に一定の相関はみられなかった。すなわち, 脳 虚血による神経脱落症状を有する症例に打いても, 血 浆中・䯣液中 $\beta$-エンドルフィンの変動は脳虚血と相関 しなかった。

脳梗塞急性期患者に打いて髄液中 $\beta$-エンドルフィ ンが上昇し, 血浆中 $\beta$-エンドルフィンには変動がみら れなかったことから naloxone の虚血脳・脊䯣に対す る効果を髄液中 $\beta$-エンドルフィンの上昇と関連づけ ている Furui らの報告9)をはじめ, 実験的脊䯑道損傷で 春髄虚血をひき扣こしたネコで血浆中 $\beta$-エンドル フィンの上昇を認めた Faden らの報告6)など, 脳・脊髄 虚血時に血浆中又は髄液中 $\beta$-エンドルフィンが上昇 するといら報告が散見されるが今回の我々の結果はそ れらを支持するものではなかった。

naloxone が脳虚血や出血性ショックに対し有効で あったとする報告4)5)の中で, その際の $\beta$-エンドルフィ ンの変動について調べたものは少ない(6)17). 一方 naloxone の虚血脳組織に対する作用は, opiodi receptorを介するものではないことを示唆する報告31132) がみられるが, そらであるとすれば, naloxone はェン ドルフィンに拮抗することにより神経脱落症状を改善 させるのではなく, 症状改善は noloxone 自身の有す る薬理作用によるものとも考兄られる。 opioid receptorのらち, $\beta$-エンドルフィンは $\varepsilon$-receptor に親和性 を有し ${ }^{29)}$, naloxone は $\mu$-receptor に親和性を有する5) とされて打り，このことからすれば, naloxone と $\beta$-エ ンドルフィンはそれ汪ど強く関係していないのかもし れない。
元来内因性モルフィン様物質として見いだされたエ ンドルフィンではあるが, 疼痛に関連する3(11)172)2427)の みでなく髄液中 $\beta$-エンドルフィンは痴呆 ${ }^{18)}$, アルコー ル中毒16)26)で低下し, 精神分裂病やそうらつ病のそう 状態で上昇する ${ }^{20)}$. 一方血中 $\beta$-エンドルフィンは下垂 体からの分泌を反映して ACTH・ $\beta$ - LPH と平行する 日内変動を有(20121)25), アシシソン病, ネルソン症候群で 上昇し，クッシング病，ステロイド投与で低下するな ど内分泌疾患との関係が示されている ${ }^{16)}$. また, ゴナド トロピン分泌との関係 ${ }^{8}$ や, 学習, 記憶との関係も示唆 されている23).

現在までに多くの神経ペプチドが発見され, それら の様々な動態についての研究がなされてきたが，脳・

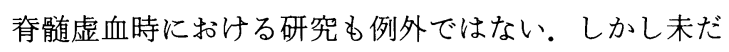
一致した見解に達しているとは言い難く, 今後さらに 検討されるべきであろう。

\section{文献}

1) Baskin DS, Kieck CF, Hosobuchi Y : Naloxone reversal of ischemic neurological deficits in baboons is not mediated by systemic effects. Life Sciences $31: 2201-2204,1982$

2) Baskin DS, Hosobuchi Y: Naloxone reversal of ischemic neurological deficits in man. Lancet $2: 272-275,1981$

3) Cleeland CS, Shacham S, Dahl JL, et al: CSF beta-endorphin and the severity of pain. Neurology 34 : 378-380, 1984

4) Curtis MT, Lefer AM: Protective actions of naloxone in hemorrhagic shock. Amer J Physiol 239 : H416-H421, 1980

5) Faden AI : Neuroleptics and stroke: Current status and potential application. Stroke $14: 169$ $-172,1983$

6) Faden AI, Jacobs TP, Smith GP, et al: Neuropeptides in spinal cord injury: Comparative experimental models. Peptides 4: 631-634, 1983

7) Flamm ES, Young W, Dompoulos HB, et al : Experimental spinal cord injury: Treatment with naloxone. Neurosurgery $10: 227-231,1982$

8) Furuhashi $N$, Takahashi $T$, Kono $H$, et al: Sex differene in the human peripheral plasma beta-endorphin and beta-lipotropin levels. Gyenecol Obstet Invest 17 : 145-148, 1984 
9) Furui $T$, Satoh $K$, Asano $Y$, et al : Increase of beta-endorphin levels in cerebrospinal fluid but not in plasma in patients with cerebral infarction. J Neurosurg 61 : 748-751, 1984

10) Gaines C, Nehls DG, Suess DM, et al : Effect of naloxone on experimental stroke in awake monkeys. Neurosurgery $14: 308-314,1984$

11) Genazzani AR, Nappi G, Facchinett F, et al : Progressive impairment of CSF beta-EP levels in migraine sufferers. Pain 18:127-133, 1984

12) Hayes RL, Galinat BJ, Kulkarne $P$, et al: Effects of naloxone on systemic and cerebral responses to experimental concussive brain injury in cats. J Neurosurg 58: 720-728, 1983

13) Holaday JW, D'Amato RJ: Naloxone or TRH fails to improve neurologic deficits in gerbil models of "stroke". Life Sciences $31: 385$ $-391,1982$

14) Hososbuchi Y, Baskin DS, Woo SK : Reversal of induced ishemic neurologic deficit in gerbils by the opiate antagonist noloxone. Science 215 : $69-71,1982$

15) Hubbard JL, Sundt TM: Failure of naloxone to affect focal incomplete cerebral ischemia and collateral blood flow in cats. J Neurosurg $59: 237-244,1983$

16）井村裕夫, 中井義勝, 中尾一和, 他 : $\beta$-エンドル フィン. 臨床科学 $17: 1483-1486,1981$

17) Jones VC: Role of the endorphins in neurology. Practitioner 227 : 487-495, 1983

18) Kaiya $H$, Tanaka $T$, Takeuchi $K$ : Decreased level of beta-endorphin-like immunoreactivity in cerebrospinal fluid of patients with senile dementia of Alzhemier type. Life Sciences 33 : 1039-1043, 1983

19) Levy R, Feustel P, Severinghaus J, et al: Effect of naloxone on neurologic deficit and cortical blood flow during focal cerebral ischemia in cats. life Sciences 31: 2205-2208, 1982

20) Lindström LH, Widerlöv E, Gunne LM, et al : Endorphins in human cerebrospinal fluid: Clinical correlations to some psychotic state.
Acta Psychiatr Scand $57:$ 153-164, 1978

21）松倉 茂, 吉見宏樹, 末岡 悟, 他: Beta-endorphin. 日本臨床 $38: 1016-1024,1980$

22) Matsumiya N, Dohi S : Effects of intravenous or subarachnoid morphine on cerebral and spinal cord hemodynamics and antagonism with naloxone in dogs. Anesthesiology $59: 175$ $-181,1983$

23）野元正弘, 出水干二：内因性ホルモン様物質と精 神機能。日本臨床 $41: 990-994,1983$

24）尾山 力：疼痛とモルヒネ様ペプチド。日本臨床 42: 907-912, 1984

25) Petraglia F, Facchinetti F, Parrini D, et al: Simultaneous circadian variations of plasma ACTH, beta-lipotropin, beta-endorphin and cortisol. Hormone Res 17 : 147-152, 1983

26) Savoldi F, Mazzela GL, Facchinetti F, et al : Beta-endorphin, beta-lipotropin and adrenocorticotropic hormone levels in cerebro-spinal fluid, and brain damage in chronic alcoholics. Eur Neurol 22 : 265-271, 1983

27) Sjölund B, Terenius L, Eriksson $M$ : Increased cerebrospinal fluid levels of endorphins after electroacupuncture. Acta Physiol Scand 100 : 382-384, 1977

28) Sugar O: Editorial: Naloxone in the treatment of stroke. Surg Neurol 18:225, 1982

29）高木博司：オピオイドペプチド. 日本臨床 41 ： 915-919, 1983

30) Turner DM, Kassell NF, Sasaki T, et al: Cerebral and systemic vascular effects of naloxone in pentobarbital-anesthetized normal dogs. Neurosurgery $14: 276-282,1984$

31) Turner DM, Kassell NF, Sasaki T, et al: High dose naloxone produces cereral vasodilation. Neurosurgery $15: 192-197,1984$

32）矢尾光憲, 本田謙一, 工藤 剛, 他：脳神経外科手 術に打ける血漿打よび脳脊䯣液中 $\beta$-エンドル フィン濃度の変動. 麻酔 $32: 504-508,1983$

33) Young W, Flamm ES, Demopoulos HB, et al: Effect of naloxone on posttraumatic ischemia in experimental spinal contusion. J Neurosurg 55 : 209-219, 1981 


\title{
Abstract \\ Plasma and CSF beta-endorphin in cerebral ischemia
}

\author{
Akira Saito, M.D., Yoko Nakasu, M.D., Hiroyuki Kitano, M.D., \\ Yasushi Hara, M.D. and Jyoji Handa, M.D. \\ Department of Neurosurgery, Shiga University of Medical Science
}

Beta-endorphin levels in plasma and cerebrospinal fluid (CSF) were measured in patients with aneurysmal subarachnoid hemorrhage with (Group 3) or without (Group 2) symptomatic spasm. All patients were operated upon on day 0 or 1 after subarachnoid hemorrhage. Patients with cerebral infarction (Group 4) and those with various neurologic disorders with or without craniotomy (Group 1, control) were also studied.

Routine craniotomy itself did not result in any abnormal levels of plasma and CSF beta-endorphin. When compared to Group 1, the postoperative course of beta-endorphin levels did not differ significantly in patients with cerebral aneurysm, either with or without development of symptomatic vasospasm. Similarly, beta-endorphin levels in patients with cerebral infarction failed to show any significant changes.

In summary, plasma and CSF levels of beta-endorphin do not seem to be an useful marker of acute cerebral ischemia.

(Jpn. J. Stroke 8: 208-212, 1086) 